\title{
The Desna River Daily Multi-Site Streamflow Modeling Using SWAT with Detail Snowmelt Adjustment
}

\author{
Valeriy Osypov ${ }^{1}$, Nataliia Osadcha ${ }^{1}$, Dmytro Hlotka ${ }^{1}$, Volodymyr Osadchyi $^{1} \&$ Juriy Nabyvanets ${ }^{1}$ \\ ${ }^{1}$ Ukrainian Hydrometeorological Institute, Kyiv, Ukraine \\ Correspondence: Valeriy Osypov, Ukrainian Hydrometeorological Institute, Kyiv, Ukraine, Nauky Prospekt, 37, \\ 03028, Ukraine. E-mail: valery_osipov@ukr.net
}

Received: July 31, 2018

Accepted: August 14, 2018

Online Published: August 30, 2018

doi:10.5539/jgg.v10n3p92

URL: http://dx.doi.org/10.5539/jgg.v10n3p92

\begin{abstract}
The Ukrainian Government started the process of EU water Directives implementation aimed at developing of the River Basin Management Plan for 9 main river catchments. The program SWAT was tested to simulate the water flow of a large plain river with a predominant snow supply. River discharges (12 gauges), snow cover depth (13 stations), and the soft data, including graphically defined surface runoff and MODIS evapotranspiration, were used to calibrate the model. The calibration flowchart, along with a detailed source data description, is proposed to aid with streamflow simulation for the snowmelt-driven watersheds and fill the existing gap of distributed hydrological modeling in the region. The main issues with snow simulation and climate data coverage are discussed. The program SUFI-2 in SWAT-CUP package was used for performing calibration/validation and uncertainty analysis. The statistics ( $\mathrm{R}^{2}$, NSE, PBIAS) showed good agreement (NS $>0.7, \mathrm{R}^{2}>0.75$, PBIAS $< \pm 10 \%$ ) for a major part of the gauges and satisfactory for all of them (NS $>0.5, \mathrm{R}^{2}>0.6$, PBIAS $< \pm 15 \%$ ), except of two linked upstream outlets. This study provides the basis for further research on water resources, the impacts of climate change, and water quality issues.
\end{abstract}

Keywords: SWAT, streamflow, calibration, snowmelt

\section{Introduction}

The public water supply as well as the planning of the development of enterprises, and their location closely depend on water availability. Within the territory of Ukraine, there are 9 big river basins. The total water resources of these basins on average are $94.1 \mathrm{~km}^{3} /$ year, and taking into account the Danube flow $-209.8 \mathrm{~km}^{3} /$ year. Nonetheless, the whole country lacks a sufficient water supply. In Ukraine, the water supply per capita is equal to $1080 \mathrm{~m}^{3} /$ year, which is below the optimal standard of $1700 \mathrm{~m}^{3} /$ year proposed by United Nations Economic Commission for Europe (ECE) (Yatsik, 2004). The insufficiency of the total water supply is compounded by an irregular distribution of water bodies along the territory, and over time. The southern and south-eastern regions, where the density of the population and manufacturing facilities reaches the maximum indices, have the smallest water supply capacities. (Palamarchuk \& Zakorchevna, 2006). Significant annual fluctuations of water flow and its longterm changes have a great impact on a hydrological budget of certain regions.

Global climate changes and their regional manifestations in Ukraine aggravate water supply concerns. A considerable change of a river hydrological regime, predominantly observed in a cold cycle, is described in the generalized works made in the mentioned above direction (Hrebin, 2010; Loboda, 2011, pp.344-356).

In Ukraine, where a large part of the public water supply is provided by surface water sources, the issue of water quality is equally important to water quantity. A longstanding disequilibrium between an extensive use of water and the self-restoration of water led to a significant deterioration of the river and lake ecological state.

After the fall of the Soviet Union the economic growth of Ukraine was extremely diminished. This was due to the compound processes of the switch to new principles of economic management, which were followed by the closure of many enterprises and population reduction. A positive ecological effect of such a shift was improved water quality as a result of decreased human pressure on water bodies (Osadchy, Nabyvanets, Linnik, Osadcha, \& Nabyvanets, 2016; Osadchy, V., Osadcha, N., \& Nabyvanets, Ju., 2003). Nevertheless, surface and ground water status did not reach the level of the1960's. This fact is explained by the following reasons: in comparison with the1990's the contemporary water usage has decreased by a factor of three, however, the low connection rate to 
the sewage systems, outdated technologies and power consumption of available sewage treatment plants, and the exceeded permissible rates of sewage discharge by waste water treatment plants lead to the contamination of aquatic ecosystems. Fifteen percent of the total quantity of the discharged sewage is still untreated.

Until recently, the input of contaminants from diffuse sources has not been considered. At the same time, the practices of many developed countries have shown that the implementation of the up-to-date management of river watersheds significantly reduces the part of the point pollution. In the water pollution, the input of contaminants from diffuse sources has assumed significant. For example, in the Danube river basin, $44 \%$ of total nitrogen and $28 \%$ of phosphorus input is due to the runoff from the watershed area (ICPDR, 2015). Thus, only the point-source discharge control leads to a significant undervaluation of the water pollution and the insufficient effectiveness for improving the ecological state.

The water governance was not reformed, was carried out based on a territory administrative principle, and was predominantly of a declarative nature. The stiff requirements to the water quality were based on the sanitarytoxicological regulatory action, not including an ecological status of separate objects. Most importantly, these stiff requirements were not accompanied by the implementation of the measures on abating negative impact, and the responsible for contamination entities were never punished.

The experience of previous years shows that the decades-long efforts in that process have not led to any notable results. The analysis of a current environmental situation in Ukraine implies a countrywide surface water contamination. According to the data from The National Report on the State of Environment in 2015, the cases of high water pollution were observed in $49 \%$ of water objects (Ministry of Ecology and Natural Resources of Ukraine, 2015). As a result of the accumulated over years' problems in the water sector, it required urgent changes in the current water management approach. A new strategic and legal framework for EU compliant have already developed. The WFD and also 5 more EU basic directives are implemented in the water sector (European Atomic Energy Community, European Union, The Member States, \& Ukraine, 2014). The strategic management aim is to achieve an ecological status by the water bodies which is close to a natural one, and the basic operating tool is the development of the river basin management plan.

The solutions to many problems connected with the implementation of the mentioned above plan now is mainly in the field of modeling. The assessment of the impact of different factors on the formation of water runoff, including climate changes, flood forecasting and overflowing risk analysis, and the planned measures effectiveness analysis are entirely connected with distributed hydrological and water quality models. The shortage of the necessary input information about streamflow formation factors, departmental affiliation of required data and data security for a wide circle of stakeholders, and the absence of a trained stuff led to technological inferiority of the country (Wellen, Kamran-Disfani, \& Arhonditsis, 2015).

The Soil and Water Assessment Tool (SWAT) model has emerged as one of the most widely used water quality watershed- and river basin-scale models worldwide, applied extensively for a broad range of hydrologic and/or environmental problems. The international use of SWAT can be attributed to its flexibility in addressing water resource problems, extensive networking via dozens of training workshops and the several international conferences that have been held during the past decade, comprehensive online documentation and supporting software, and an open source code that can be adapted by model users for specific application needs (Gassman, Sadeghi, \& Srinivasan, 2014).

For the East European Plain rivers, the accurate prediction of snow accumulation and subsequent snowmelt is an essential component of integrated hydrological and water quality models because snowmelt runoff is approximately $60-75 \%$ of the total surface runoff (Sokolovsky, 1968). Globally, the snowmelt-related applications of SWAT are limited and the results some of them are unsatisfactory due to a lot of influences that the model cannot account for (Gassman, Reyes, Green, \& Arnold, 2007).

Therefore, the main goal of this article is to provide a SWAT guideline for a plain stream flow modeling of the rivers with a primary snowmelt supply.

\section{Method}

\subsection{Model Description}

SWAT (Soil and Water Assessment Tool) is process based, semi-distributed, continuous-time model (Arnold et al., 2012). The program operates on a daily time step and is designed to predict the impact of land use and management on water, sediment, and agricultural chemical yields. Major model components include weather, hydrology, soil temperature and properties, plant growth, nutrients, and land management. In SWAT, a watershed is divided into multiple subbasins, which are then further subdivided into hydrologic response units (HRUs) that 
consist of unique land use, soil type, and slope. The HRUs are represented as a percentage of the subbasin area and may not be contiguous or spatially identified within a SWAT simulation.

Water balance is the driving force behind all the processes in SWAT because it impacts plant growth and the movement of sediments, and nutrients. Simulation of watershed hydrology is separated into the land phase, which controls the amount of water, sediment, and nutrient to the main channel in each subbasin, and the in-stream or routing phase, which is the movement of water, sediments, nutrients through the channel network of the watershed to the outlet.

\subsection{Study Area and Data}

The study area was the Desna River watershed. It is one of the five subbasins of the Dnipro River, which is the biggest watershed of Ukraine and the Europe third largest river. The Desna is the main public water supply source in the capital of Ukraine, Kyiv. According to the data of Kyiv public water supply company Kyivvodokanal, the Desna provides $85 \%$ of daily water demand (Kyivvodokanal, 2018).

The Desna basin covering $88,800 \mathrm{~km}^{2}$ is located within the Russian Federation (RF) (68\%) and Ukraine (32\%). The river begins in RF on the Smolensk highland and drains the Dnipro near Kyiv passing through 6 regions of RF and after crossing the boundary -3 regions of Ukraine.

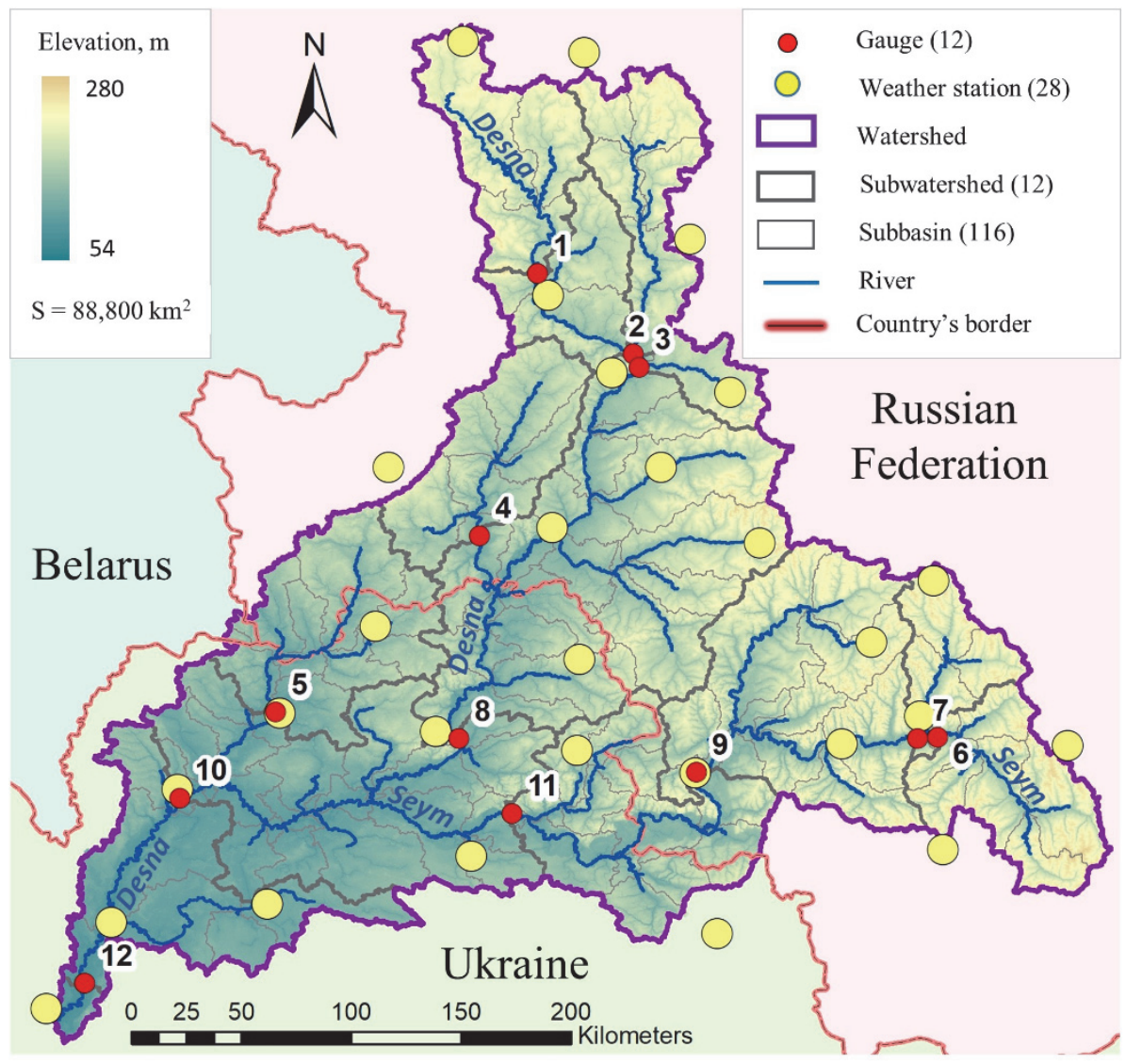

Figure 1. The Desna watershed with SWAT-delineated subbasins, gauge's subwatersheds, digital elevation model, river network, and weather stations.

Formation of the hydrographic network of the Desna basin is driven by a complex of physicogeographical factors, among which the landscape, climate conditions, geological structure, and hydrogeological characteristics of the territory play a primary role.

The main part of the basin is occupied by the Dnipro-Donetsk Rift. To the East from it, there are the spurs of the Voronezh crystalline core-area which is a lower end of the Central Russian Upland. In this regard, the right river bank of the Desna is mainly a valley side and sharply breaks (till $100 \mathrm{~m}$ ) towards the flood bed. The local base level of erosion depth increases till 100-125 m and, in some places, till $150 \mathrm{~m}$. The presence of a well erodible Cretaceous deposits leads to a considerable roughness. The density of the ravine network in this part exceeds 1 
$\mathrm{km}^{2}$ (Marynich \& Shishchenko, 2005). Cretaceous and Paleogene deposits are situated above the local erosion base level; the first ones are exposed on the Desna valley slopes.

Due to multiple continental glacier invasions, moraine, glaciofluvial and alluvial sands, and sandy loams predominate in the anthropogenic depositions of the Desna basin. The domination of these depositions led to the formation of the mainly erosional landforms.

Table 1. Data description and sources used in the SWAT model of the Desna watershed

\begin{tabular}{|c|c|c|}
\hline Data type & Resolution & Source \\
\hline DEM & $25 \mathrm{~m}$ & Modified SRTMGL1, https://earthexplorer.usgs.gov/ \\
\hline Soils & $1: 2500000$ & $\begin{array}{l}\text { Merged Ukrainian (http://padaread.com/?book=47519\&pg=226) and Russian atlases } \\
\text { (http://atlas.mcx.ru/materials/egrpr/content/data.html) }\end{array}$ \\
\hline Land use & $25 \mathrm{~m}$ & $\begin{array}{l}\text { Merged GlobeLand30 LULC (http://www.globallandcover.com/GLC30Download/index.aspx) } \\
\text { and Global Forest Change, } 2012 \text { forest state (https://earthenginepartners.appspot.com/science- } \\
\text { 2013-global-forest) }\end{array}$ \\
\hline $\begin{array}{l}\text { River network } \\
\text { dataset }\end{array}$ & Fine; Variable & $\begin{array}{lcccc}\text { filtered } & \text { OpenStreetMap } & \text { vector } & \text { "waterway" } & \text { layers, } \\
\text { https://download.geofabrik.de/europe/ukraine.html } & & \\
\end{array}$ \\
\hline \multirow[t]{2}{*}{ Climate } & \multirow{2}{*}{$\begin{array}{l}\text { Observed } 38 \text { stations } \\
\text { (daily) }\end{array}$} & rp5.ru (22 Russian \& Belarus stations): $\mathrm{t}_{\max }, \mathrm{t}_{\min }$, precipitation, humidity, wind, cloud coverage \\
\hline & & $\begin{array}{l}\text { Central Geophysical observatory (16 Ukrainian stations): } t_{\max }, t_{\min } \text {, precipitation, humidity, wind, } \\
\text { cloud coverage }\end{array}$ \\
\hline \multirow[t]{2}{*}{ Snow cover } & \multirow[t]{2}{*}{ Observed 13 stations } & $\begin{array}{l}\text { European Climate Data Center (ECAD), www.ecad.eu (6 Russian stations), daily snow depth in } \\
\mathrm{cm}\end{array}$ \\
\hline & & Central Geophysical observatory (7 Ukrainian stations), snow depth in $\mathrm{mm} \mathrm{H}_{2} \mathrm{O}$ every 5 days \\
\hline \multirow[t]{2}{*}{$\begin{array}{l}\text { River } \\
\text { discharge }\end{array}$} & \multirow[t]{2}{*}{12 guages } & $\begin{array}{l}\text { Automatic Information System of National Monitoring of Water Bodies (7 RF gauges), } \\
\text { https://gmvo.skniivh.ru/ }\end{array}$ \\
\hline & & Central Geophysical observatory (5 Ukrainian gauges) \\
\hline \multirow{2}{*}{$\begin{array}{l}\text { Crops } \\
\text { (planting, } \\
\text { fertilizers, } \\
\text { yield) }\end{array}$} & \multirow{2}{*}{$\begin{array}{l}\text { Wheat, rye, hay, } \\
\text { barley, oats, corn, } \\
\text { sunflower, sugarbeet, } \\
\text { potato }\end{array}$} & 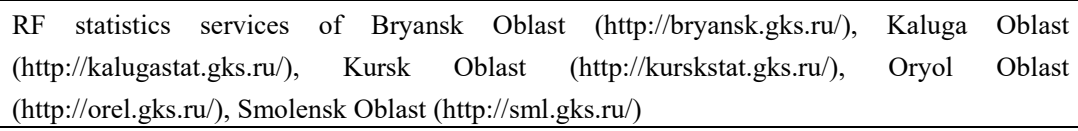 \\
\hline & & $\begin{array}{l}\text { State statistics Service of Ukraine (http://www.ukrstat.gov.ua/), statistics services of Chernihiv } \\
\text { Oblast (http://www.chernigivstat.gov.ua/), Sumy Oblast (http://sumy.ukrstat.gov.ua/) }\end{array}$ \\
\hline
\end{tabular}

Note. ${ }^{\text {a }}$ depends on the satellite images resolution for the specific part of the Basin and proficiency of the OpenStreetMap volunteer to interpret the image part and build a river network vector layer

Generally, the Desna basin elevation varies within 100-227 m. Inside the Dneprovsko-Donets Rift, there are Poliska Lowland and Prydniprovska Lowland splitted by widely meandering river valleys. The depth of the local base erosion level varies within $25-27 \mathrm{~m}$.

The Desna is a typical plain stream with a slight slope of $1 \mathrm{~m} / \mathrm{km}$ average. Therefore, the river channel is shaped and its width is $\sim 150 \mathrm{~m}$. The depth primarily varies within $2-4 \mathrm{~m}$ but maximum depth reaches $17 \mathrm{~m}$.

About $40 \%$ of the Desna basin is covered with soddy-podzolic soil on the glaciofluvial and moraine deposits. The better drainage conditions in the Voronezh crystalline core-area and on the higher grounds led to formation of the grey forest soils and chernozem which occupy $14.2 \%$ and $12.3 \%$ of the basin territory, correspondingly. The alluvial soils are abundant in the bottomland plots. Due to the conducted land-clearing, the modern bogginess factor is $8.3 \%$.

One third of the basin is occupied by conifer and deciduous forests; there are greenlands in the flood beds.

The annual average temperature in the Desna basin varies from $6.3^{\circ} \mathrm{C}$ in the upper half till $7.0^{\circ} \mathrm{C}$ in the lower one (Kyiv).

The Desna basin is characterized by a good wetness. Annual values of precipitation are $650-700 \mathrm{~mm}$. The majority of precipitation falls in a warm period of the year $(425 \mathrm{~mm})$, the maximum falls in June-July. The continuous rains are not a rare phenomenon, almost the half of the days per year is with precipitation. A stable snow cover is set on average in the second half of December and lasts 90-100 days. The snow cover depth is $15-35 \mathrm{~cm}$, the soil freezing reaches $15-35 \mathrm{~cm}$. The peat lands usually freeze less.

The water flow of the Desna is highly irregular during the year. Its main part is formed during the snowmelt period. 
The average long-term discharge during the spring flood is $1930 \mathrm{~m}^{3} / \mathrm{sec}$ and the maximum value is $8090 \mathrm{~m}^{3} / \mathrm{sec}$ (1917).

For the Russian part of the Desna basin, the SWAT model was constructed using freely available information (Table 1). Therefore, the climate and discharge data used in this study includes only 2008-2014 years. For the Ukrainian part, the corresponding data was provided by the Central Geophysical Observatory.

The regular meteorological observations of the Ukrainian and Russian stations do not include solar radiation data which is needed for SWAT calculations. Therefore, the standard values (cloudless weather) of solar radiation were gathered for the given station locations (Photovoltaic Geographical Information System, 2018), and the interference of cloud coverage was estimated according to the formula (Matveev, 1984):

$$
\mathrm{Q}=\mathrm{Q}_{0} \cdot(1-(a+b n) n)
$$

where $\mathrm{Q}_{0}$ - the flux of total radiation in a cloudless sky; $n$ - cloud coverage (fraction); $a$, $b$ - empirical coefficients depending on latitude (for the Desna river basin $b=0.38, a=0.4$ ).

Land use map was constructed from GlobeLand30 database, which classification is similar to the used one in SWAT NLCD1992 (National Land Cover Database). The accuracy of the forest cover is improved by merging with Global Forest Change layer (Hlotka, 2017). The management practices of the crop lands were set up into the model using the information of the regional departments of statistics of RF and Ukraine.

The soil map of the Desna basin is vectorized and merged map from Ukrainian (1977-1993) and Russian (2008) soil atlases. The map is allocated 30 soil groups according to Dokuchaev classification (USSR 1977). In this classification, the genetic approach is applied and each class is described by step nomenclature: type, subtype, genus, kind, variant, and category. The first four stages characterize the soil-forming processes, and only a variant of soil indicates the texture of the soil layer. Generally, the soil group is allocated on the basis of the first 3-4 steps and does not take into account the soil texture which is more important for identification of an average water capacity, infiltration and permeability properties of the soil layer, as well as surface and lateral flows (Medvedev \& Laktionova, 2011). Therefore, some polygons of the same soil group but with different soil texture are identified as unique ones. As the result, the final map for the SWAT project contains 37 soil classes.

The required soil parameters are collected from literature (Medvedev \& Laktionova, 2011), the digital atlas of Soils of Ukraine (Medvedev, Laktionova, \& Gayvoronsky, 2006), and Unified State Register of soil resources in Russia (USRSRR) for the territory of the RF (USRSRR, 2018). The saturated hydraulic conductivity (SOL_K) for the Ukrainian part of the basin is collected from the digital map of soil filtration (Maps of Ukraine, 2016). For the Russian part of the basin, SOL_K is determined in two stages. First, the texture class is defined according to N. A. Kaczynski classification (Medvedev \& Laktionova, 2011, p. 34). Further, Table 2 provides the most probable SOL_K values. The range indicated in brackets can serve as a guideline for subsequent calibration.

Table 2. Saturated hydraulic conductivity of the soil texture class (the most probable range in parentheses) (Medvedev \& Laktionova, 2011, p. 269)

\begin{tabular}{lc}
\hline Soil texture class & Saturated hydraulic conductivity, cm/day \\
\hline Loose sand & $>150$ \\
Cohesive sand & $150(80-200)$ \\
Loamy sand & $100(50-150)$ \\
Sandy loam & $80(40-120)$ \\
Silty loam & $50(30-70)$ \\
Clay loam & $40(20-70)$ \\
Clay & $15(2-30)$ \\
\hline
\end{tabular}

\subsection{Performance Criteria}

Coefficient of determination, Nash-Sutcliffe efficiency, and PBIAS were used to evaluate the model performance. These criteria were selected because of their frequent use in the world practice, which made it possible to compare results with other similar works (Moriasi, Gitau, Pai, \& Daggupati, 2015).

Coefficient of determination: 


$$
R^{2}=\frac{\left[\sum_{i}\left(Q_{m, i}-\bar{Q}_{m}\right)\left(Q_{s, i}-\bar{Q}_{s}\right]^{2}\right.}{\sum_{i}\left(Q_{m, i}-\bar{Q}\right)^{2} \sum_{i}\left(Q_{s, i}-\bar{Q}\right)^{2}}
$$

where $Q_{m}$ - measured value, $Q_{s}$ - simulated value. The same indexes are used below. $R^{2}$ ranges from 0 to 1 .

Nash-Sutcliffe efficiency:

$$
N S=1-\frac{\sum_{i}\left(Q_{m}-Q_{s}\right)_{i}^{2}}{\sum_{i}\left(Q_{m, i}-\bar{Q}_{m}\right)^{2}}
$$

NS ranges from $-\infty$ to 1.

Percent bias (PBIAS):

$$
\text { PBIAS }=100 \frac{\sum_{i=1}^{n}\left(Q_{m}-Q_{s}\right)_{i}}{\sum_{i=1}^{n} Q_{m . i}}
$$

Percent bias measures the average tendency of the simulated data to be larger or smaller than the observations. The optimum value is zero. Positive values indicate model underestimation and negative values indicate model overestimation.

To quantify the fit between simulation result, expressed as 95PPU, and observation, expressed as a single signal (with some error associated with it), $p$-factor and $r$-factor are used (Abbaspour, 2015). In this project, the error of $10 \%$ is associated with discharge and $20 \%$ with snow cover height observations. The $p$-factor is the fraction of measured data (plus its error) bracketed by the 95PPU band and varies from 0 to 1 , where 1 indicates $100 \%$ bracketing of the measured data within model prediction uncertainty. On the other hand, the $r$-factor is the ratio of the average width of the 95PPU band and the standard deviation of the measured variable. For $p$-factor, a value of $>70 \%$ for discharge is suggested, while a value of $<1.5$ would be desirable for $r$-factor (Abbaspour, Rouholahnejad, Vaghefi, Srinivasan, Yang, \& Kløve, 2015).

Automatic calibration, uncertainty analysis, and performance criteria calculation are now directly incorporated in SWAT2009 via the SWAT-CUP (Calibration and Uncertainty Programs) software developed by EAWAG (2009).

\subsection{Model calibration}

One of the main problems of inverse modeling is equifinality or non-uniqueness of parameters, in other words, when different combinations of input model parameters lead to the similar good solutions. In order to minimize this effect, it is necessary to calibrate several output variables. Therefore, the observations of 12 gauges and 13 snow survey stations were used for streamflow calibration in the Desna watershed. The parameters of the model are calibrated simultaneously for the whole watershed, in such a way as to be suitable for each gauge, rather than the calibration for each subwatershed separately because it would lead to equifinality of each subwatershed as well. Exception can be justified for some parameters, which reflect topography and geological features of a catchment (e.g. groundwater parameters, time of surface flow concentration). It can be argued that each parameter can be precisely the same for the whole watershed but this assumption to calibration is the most reasonable option that can be exercised, based on the availability and quality of existing datasets in the watershed.

The calibration period is 4 years (2008-2011) and the validation period is 3 years (2012-2014). It is recommended that the calibration and validation periods should include a comparable number of dry, average, and wet years (Arnold et al., 2012). In this case, the model can compute well-balanced parameter values for the years with different water levels. The non-fulfillment of this condition increases the likelihood of unsatisfactory model validation. In this study, the periods of 2008-2011 and 2014 are classified as dry years (flow duration curve P > $66 \%), 2012$ falls within the borderline between dry and average years $(\mathrm{P}=65 \%), 2013$ - average year $(66 \%>\mathrm{P}>$ $33 \%$ ) (Koshkina, 2017). However, the hydrograph of 2010 is comparable with the hydrograph of 2012 and 2013, and the hydrograph of 2008, 2009, 2011 with 2014. Therefore, climate data used for both calibration and validation is not substantially different.

While calibration and validation are essential to ensuring model accuracy and precision, there is little consistency in how model practitioners conduct, document, and report this process (Moriasi et al., 2016). Improved reporting 
of calibration and validation procedures and results, perhaps guided by a set of standard reporting guidelines, is essential for adequate interpretation of each study and comparison among studies in the future (Arnold et al., 2012). To account on this issue, the authors (Arnold et al, 2012) summarize the parameters used in 64 studies and in studies previously summarized by Douglas-Mankin et al. (2010), and Tuppad et al. (2011) (Table 3).

Table 3. Calibration parameters reported in 64 selected SWAT watershed studies ${ }^{a}$. Numbers in parentheses are the number of times the parameter was used in calibration. Definitions of variables are found in the SWAT user manual (http://swatmodel.tamu.edu/documentation)

\begin{tabular}{|c|c|c|c|c|c|c|}
\hline Process & & & & ut Parame & ers & \\
\hline Surface runoff & $\begin{array}{l}\mathrm{CN} 2 \\
(36)\end{array}$ & $\begin{array}{l}\text { AWC } \\
(28)\end{array}$ & $\begin{array}{l}\text { ESCO } \\
(23)\end{array}$ & $\begin{array}{l}\text { EPCO } \\
(10)\end{array}$ & $\begin{array}{l}\text { SURLAG } \\
\text { (22) }\end{array}$ & $\mathrm{OV}_{(8)} \mathrm{N}$ \\
\hline Baseflow & $\begin{array}{l}\text { ALPHA_B } \\
(28)\end{array}$ & $\begin{array}{l}\text { (18) } \\
\text { (18EVA }\end{array}$ & W_DELA & $\begin{array}{l}\text { GWQMN } \\
\text { (12) }\end{array}$ & $\begin{array}{l}\text { REVAPMN } \\
\text { (13) }\end{array}$ & $\begin{array}{c}\mathrm{RCHRG}_{(14)} \\
\mathrm{C}^{\mathrm{R}} \mathrm{DP}\end{array}$ \\
\hline Snow & $\begin{array}{l}\text { SFTMP } \\
\quad(11)\end{array}$ & $\begin{array}{l}\text { SMFMN } \\
\quad(14)\end{array}$ & $\begin{array}{l}\text { SMFMX } \\
\quad(18)\end{array}$ & $\begin{array}{l}\text { SMTMP } \\
\text { (13) }\end{array}$ & $\begin{array}{l}\text { TIMP } \\
(7)\end{array}$ & $\begin{array}{l}\text { SNO50COV SNOCOVMX } \\
\text { (4) }\end{array}$ \\
\hline
\end{tabular}

Note. ${ }^{a}$ The part of the table, which concerns water flow components

The list in Table 3 does not mean that all parameters should be used for calibration. Rather, it is recommended to minimize their number, as this reduces the total uncertainty of the model (Malone et al., 2015). Basically, the most sensitive and uncertain parameters are selected for calibration. In addition to the parameters that were given in Table 3, the parameter DEP_IMP was added to reflect the relative impermeability of the illuvial horizon of sodpodzolic soils (Medvedev \& Laktionova, 2011), which are widespread in the Desna river basin. To calculate instream flow velocity, Manning's "n” value for the main channel (CH_N2) is added as well.

Taking into account that the snowmelt runoff is the major component of surface runoff, the snowmelt parameters optimization was the first step of the model calibration (Figure 2). Second, soft data is used to constrains the balance between evapotranspiration (ET) and surface runoff. Third, the runoff curve number (CN2) and the soil evaporation compensation factor (ESCO) that governs the surface runoff response along with evapotranspiration were calibrated to adjust the magnitude of hydrograph peaks. The upper subwatersheds were calibrated first, and the parameters in that subwatershed were then held constant while the downstream subwatersheds were calibrated. Further, the snow pack temperature lag factor (TIMP), along with the surface runoff lag coefficient (SURLAG) and Manning's "n" value for the main channel (CH_N2) were calibrated by matching the timing of peaks following groundwater parameters optimization (ALPHA_BF, GW_DELAY, GW_QMN, DEP_IMP, RCHRG_DP) so that the measured dry weather flow versus simulated one agreed well. Finally, this preliminary calibration was followed by a fine-tuning auto-calibration within SWAT-CUP in such a way that the predicted versus measured peak flows and recession curves matched as close as possible.

The data of the Ukrainian and Russian stations is different. Seven Ukrainian snow survey stations collect snow cover data in $\mathrm{mm} \mathrm{H}_{2} \mathrm{O}$ with a five-day interval, and 6 Russian stations collect daily snow cover height data in $\mathrm{cm}$. The preliminary results indicated that auto-calibration procedure overestimated the snowmelt rate in the most cases (Figure 3) and did not capture the date of snow cover loss, which incorrect determination shifted the phase of the spring flood on the simulated hydrograph. For this reason, the snow parameters were manually calibrated by visual inspection of 24 daily time-series plots of 6 Russian stations (4 years times 6 stations) (Figure 4). Further, the obtained ranges were verified on 7 Ukrainian stations to confirm the simulation accuracy of snow cover volume in $\mathrm{mm} \mathrm{H}_{2} \mathrm{O}$. 


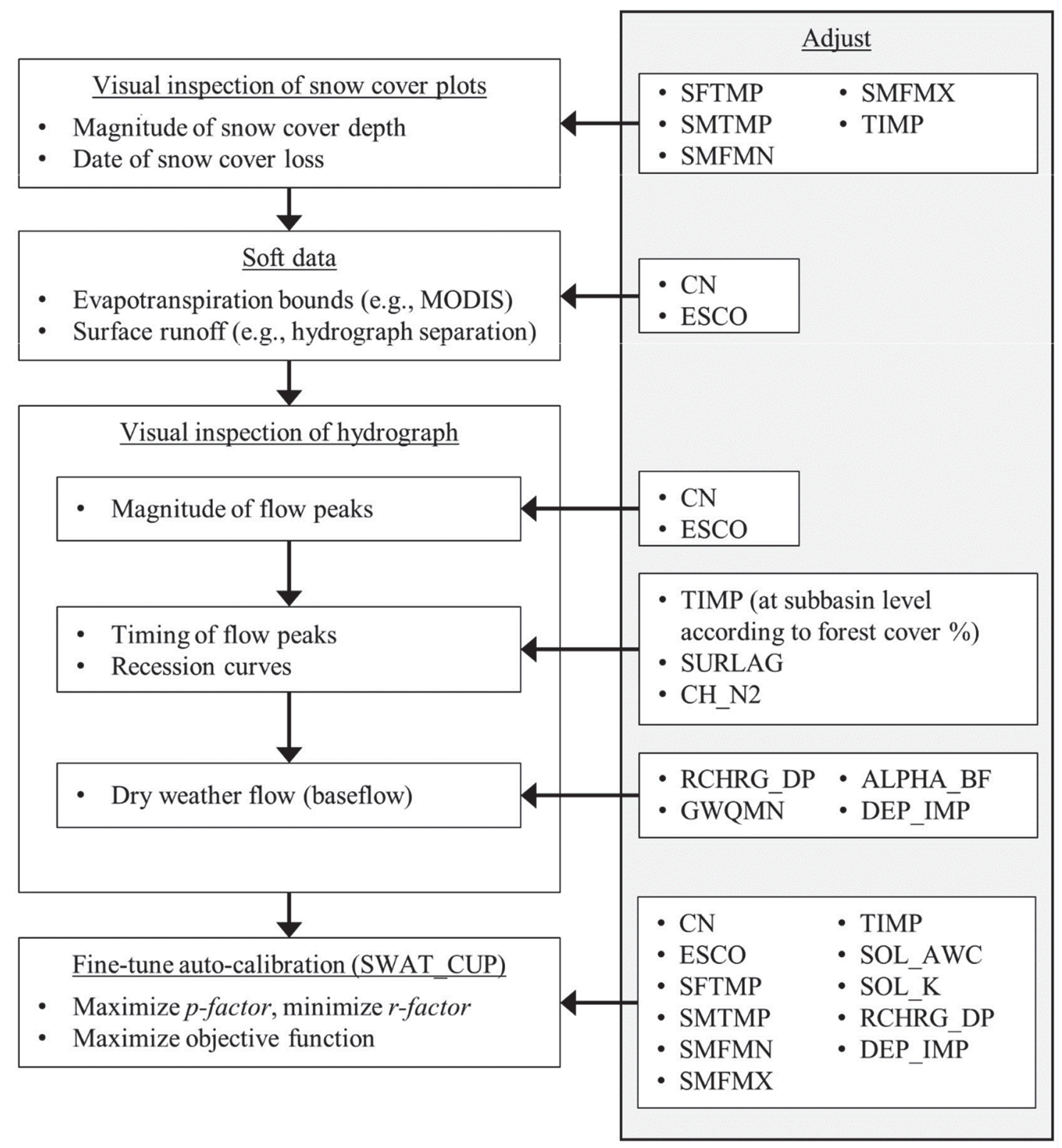

Figure 2. SWAT calibration flowchart
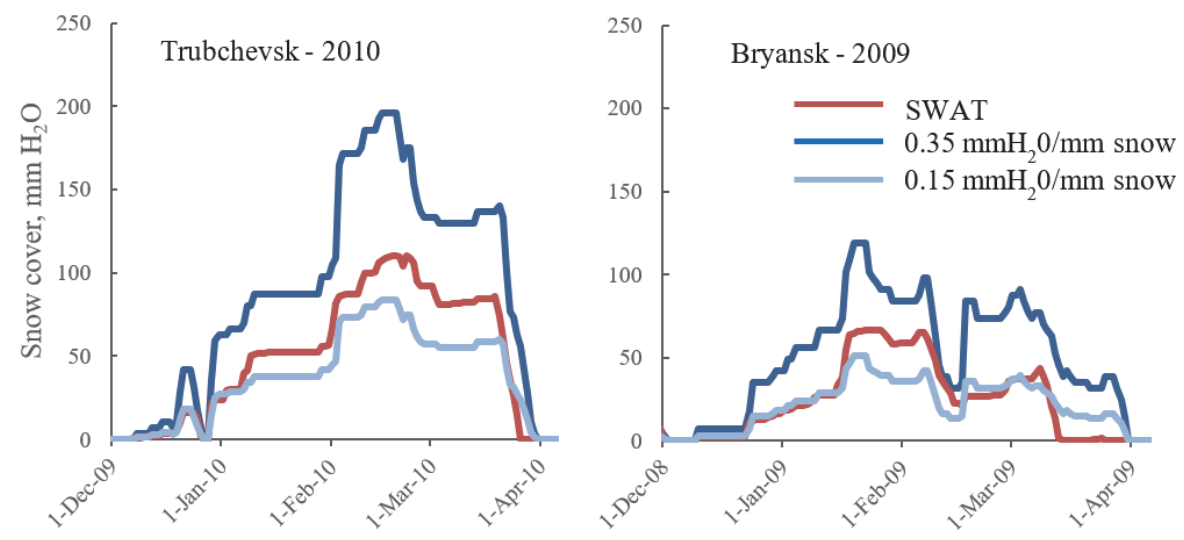

Figure 3. Example of the visual inspection of the auto-calibrated snow parameters $(\mathrm{SFTMP}=0.75, \mathrm{SMTMP}=$ $0.35, \mathrm{SMFMN}=5.54, \mathrm{SMFMX}=2.88, \mathrm{TIMP}=0.67)$. The range of snow pack density was set to $0.15-0.35 \mathrm{~mm}$ $\mathrm{H}_{2} \mathrm{O} / \mathrm{mm}$ snow in order to convert observations and examine model outputs with them 

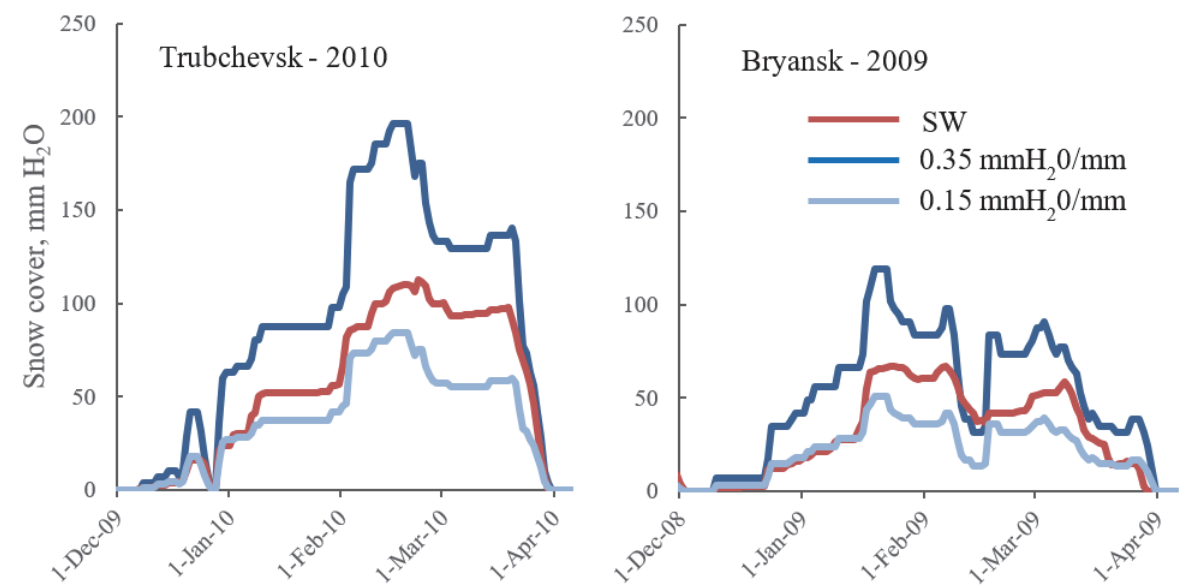

Figure 4. Example of the visual inspection of the manually optimized snow parameters ( $\mathrm{SFTMP}=0, \mathrm{SMTMP}=$

$$
0, \operatorname{SMFMN}=3, \operatorname{SMFMX}=1, \operatorname{TIMP}=0.6 \text { ) }
$$

In summary, only 3 cold periods dropped out from 28 (4 years multiply 7 Ukrainian stations). Figure 5 provides examples of good and unsatisfactory simulations. As illustrated by the arrows, there is a discrepancy in a certain short period in the first half of winter but further dynamics almost repeats observations. The more in-depth analysis of climate data indicated that the issue dealt with one storm-event that the model could not account for such as heavy rain which accelerated snowmelt, or precipitation when the temperature fluctuated around $0^{\circ} \mathrm{C}$ during the day.

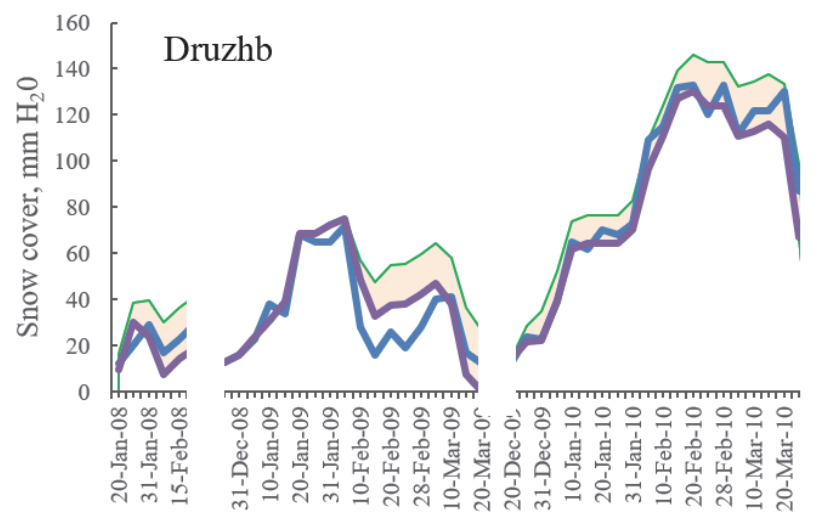

$$
\begin{aligned}
& \mathrm{NS}=0.94 \\
& \mathrm{PBIAS}=
\end{aligned}
$$
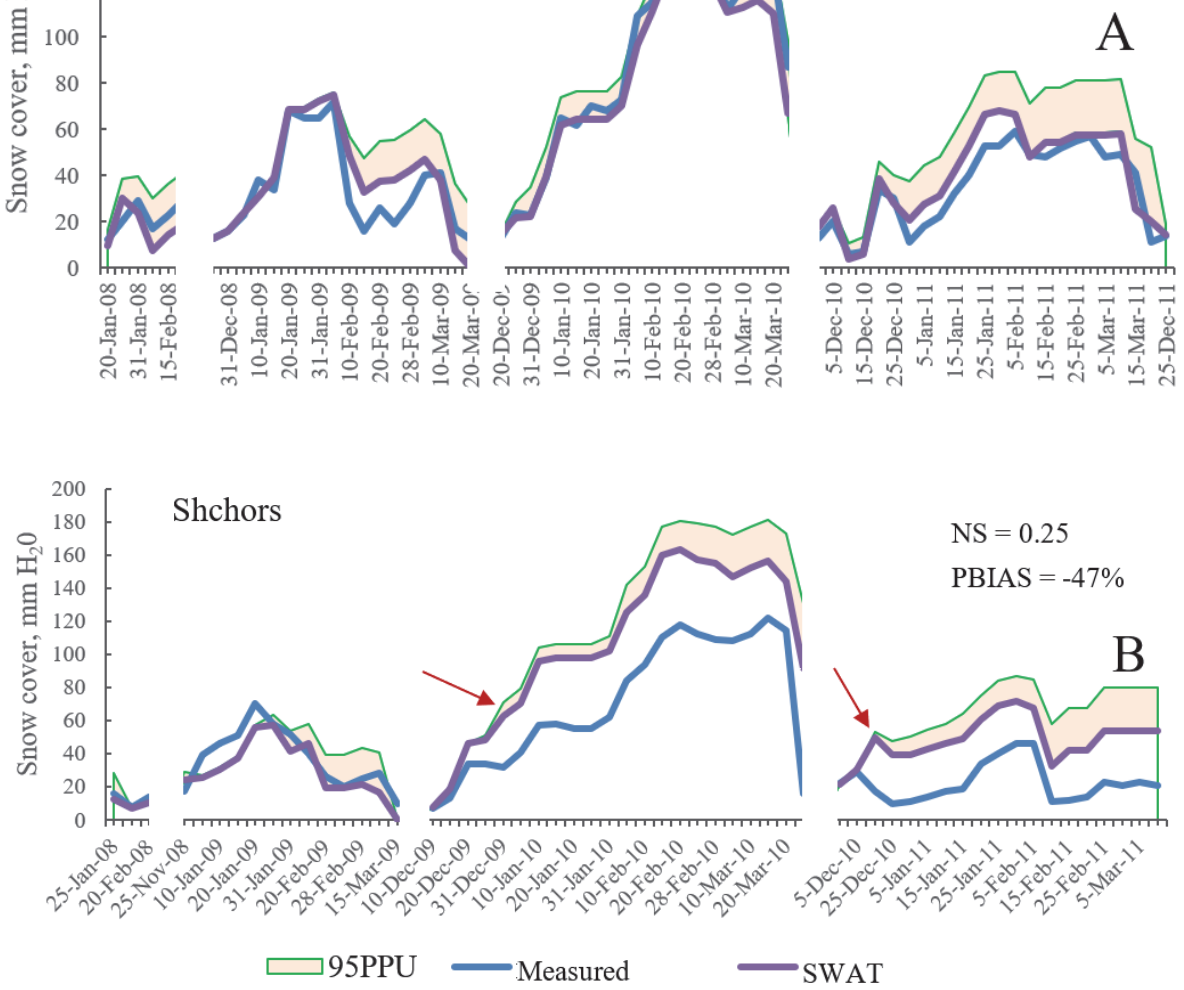

Figure 5. Measured snow cover depth, best simulation, and 95\% model uncertainty at Ukrainian snow survey stations 
Advantages of developing soft data for the calibration are the following: (1) require a basic understanding of processes (water, sediment, nutrient, and carbon budgets) within the spatial area being modeled, and (2) constrain the hard data calibration within realistic bounds (Moriasi et al., 2016). According to the graphical methods of hydrograph separation, it was established that in the present period the fraction of the surface runoff of the Desna was $45 \%$ on the average, and could fluctuate between $40-55 \%$ (Grebin \& Vasylenko, 2010). The runoff depth for the period 2008-2014 is approximately $100 \mathrm{~mm}$. Consequently, the average surface runoff depth of this period should range between $40-55 \mathrm{~mm}$. Based on this consideration, the coefficient CN2 should be reduced by $20-30 \%$ compared to the default value. According to MODIS (NASA's Moderate Resolution Imaging Spectroradiometer), the average annual evapotranspiration (ET) of the Desna watershed is $432 \mathrm{~mm}$ for the period 2000-2011 (Esri Mapping Center, 2017). This method of estimating ET was validated by field observations in more than 200 catchments around the world (Qiaozhen, Maosheng, \& Steven, 2013), consequently, the above value was taken as the starting point but keeping in mind that these were still modeled approximate values. ESCO was the most sensitive parameter for ET, and it was reduced from default value 1 to 0.4-0.6.

The snow parameters were calibrated by observations in the open terrain. At the same time, the snow survey measurements were carried out in the forest at 2 Ukrainian stations (Shchors, Semenivka). According to the observed time-series plots, the snowmelt process has some delay in the forest (Figure 6). For example, there was a short period of thaw in mid-January 2011 at Shchors station, as a result of which, the snow cover in the field decreased approximately 4 times to $10 \mathrm{~mm} \mathrm{H}_{2} 0$, and only 2 times to $20 \mathrm{~mm} \mathrm{H}_{2} 0$ in the forest (Figure 6A). Actually, the resulting gap lasted until the period of spring warming. At Semenivka station in 2011, the snow cover was almost the same until the beginning of the spring thaw, during which the snow melted much faster in open terrain. Namely, there was no snow on March 25 in the field but in the forest, the height was $30 \mathrm{~mm} \mathrm{H}_{2} \mathrm{O}$ from the starting $70 \mathrm{~mm}$, on March $31-10 \mathrm{~mm} \mathrm{H}_{2} \mathrm{O}$ (Figure 6A). Obviously, this effect is explained by the fact that the forest cover adds protection from sunlight and keeps the cold air longer during the warming period.
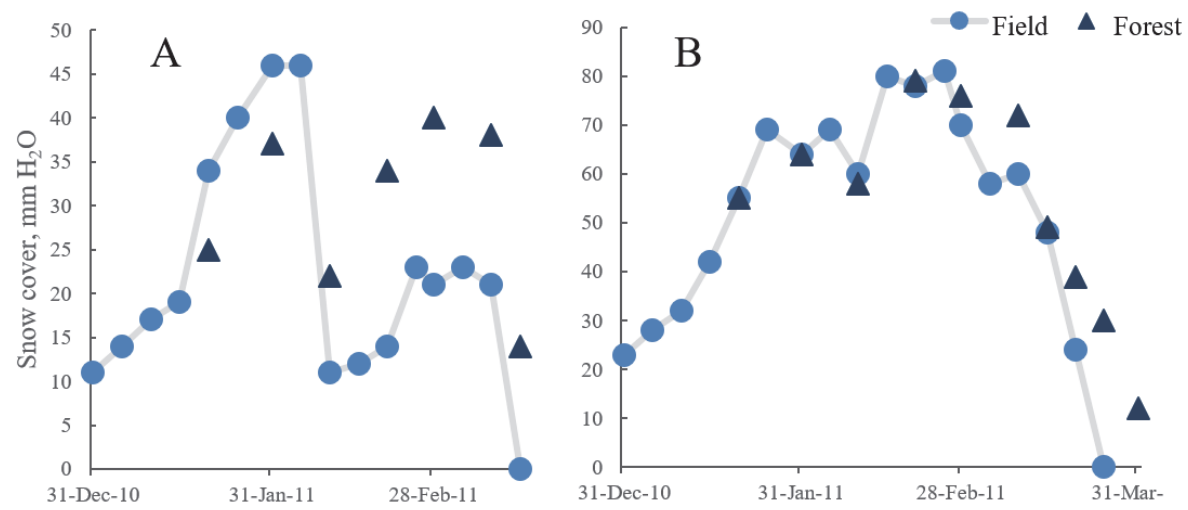

Figure 6. Comparison of snow survey observations in the field and in the forest. A - Shchors, 2011; B Semenivka, 2011

Table 4. TIMP values depending on the forest cover

\begin{tabular}{cc}
\hline Forest & TIMP \\
\hline$<11 \%$ & 0.6 \\
$11 \%-15 \%$ & 0.5 \\
$16 \%-25 \%$ & 0.4 \\
$26 \%-35 \%$ & 0.3 \\
$36 \%-50 \%$ & 0.2 \\
$>50 \%$ & 0.1 \\
\hline
\end{tabular}

The forest cover of subwatersheds varies from $11 \%$ to $60 \%$ (Figure 7). This gave an opportunity to optimize TIMP value by visual inspection of the hydrographs with different forest cover ratio (Table 4), as a result, to slow down the snowmelt proportional to the forest cover percent. As an example, the described process is depicted on the hydrograph of Gauge 1 (Figure 8). As illustrated, the model simulated the higher melting rate with TIMP $=0.5$ which caused the shifting of the spring flood hydrograph to the left. However, after optimization (TIMP $=0.1$ ), the peak of discharge was shifted to the right and the phases matched. 


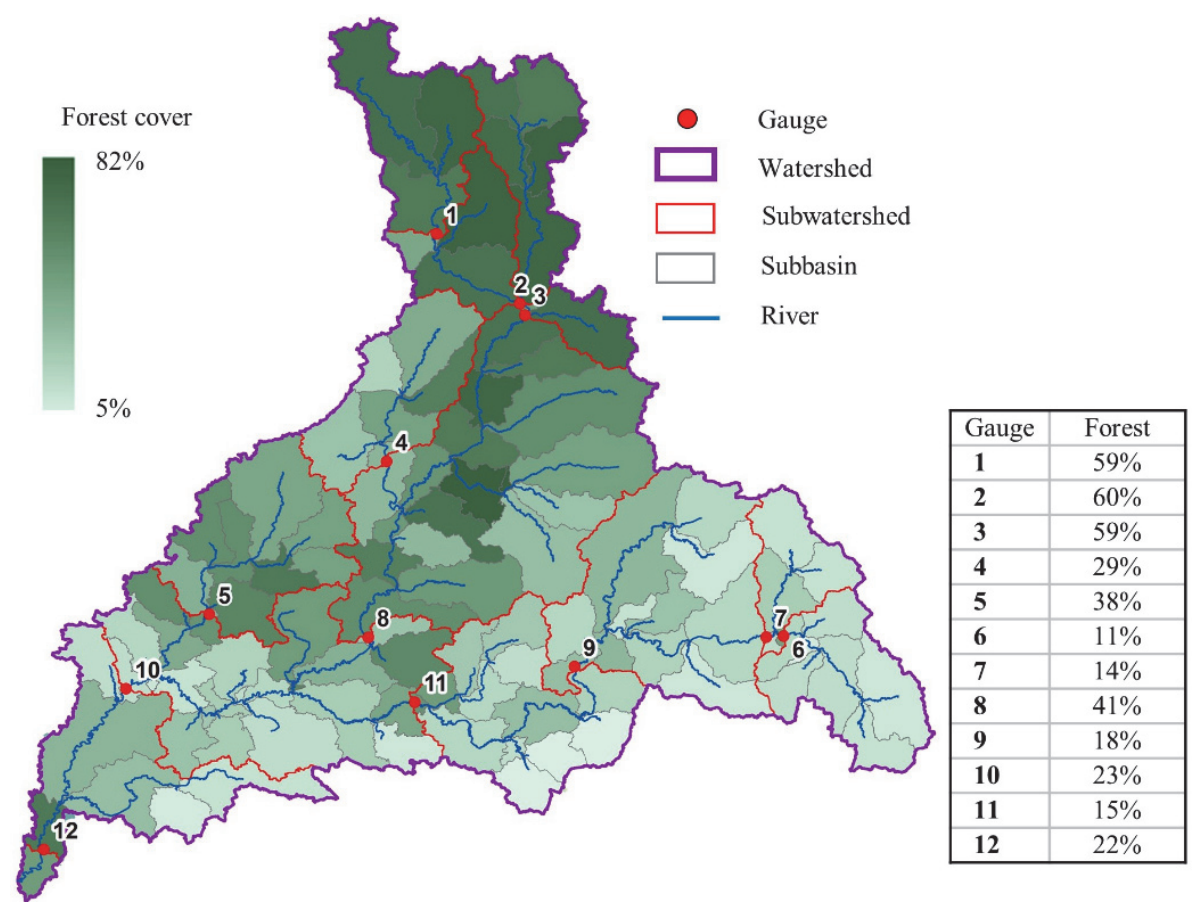

Figure 7. Forest cover (\%) of the Desna river basin aggregated according to SWAT-delineated subbasins
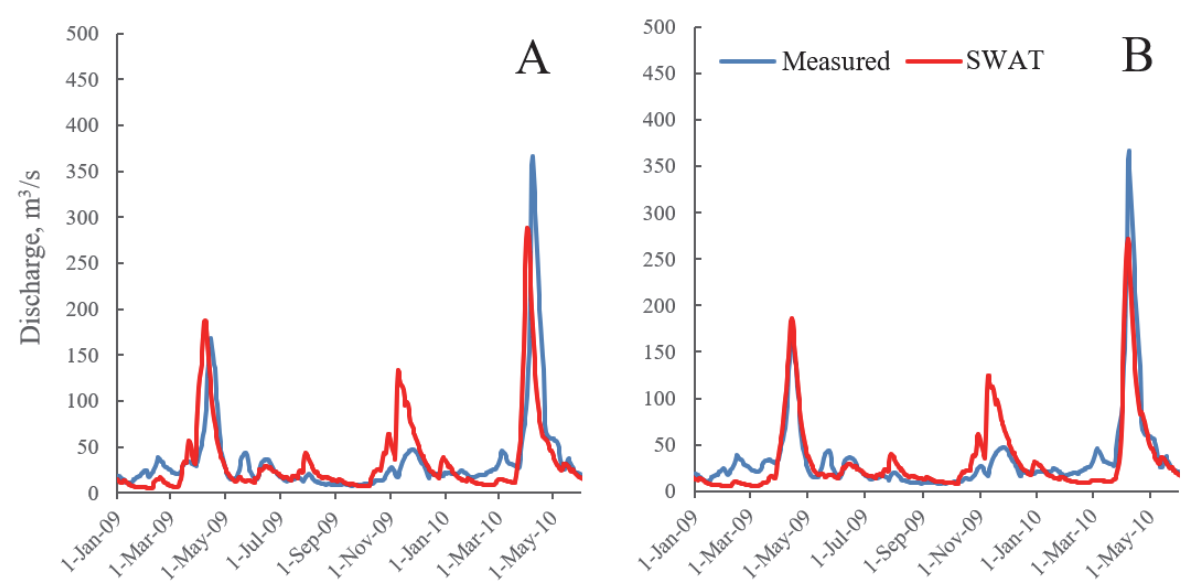

Figure 8 . The example of the snowmelt optimization according to the forest cover ratio (Gauge 1, forest $-59 \%$ ).

$$
\mathrm{A}-\mathrm{TIMP}=0.5, \mathrm{~B}-\mathrm{TIMP}=0.1 \text {. }
$$

The final parameter ranges as well as the values of the best simulation were determined by SWAT-CUP based on the recommendations of desirable $p$-factor and $r$-factor values (Table 5).

\section{Results}

According to the common performance evaluation criteria for watershed-scale models (Moriasi et al., 2015), the final calibration results are satisfactory (NS $>0.5, \mathrm{R}^{2}>0.6$, PBIAS $< \pm 15 \%$ ) for all twelve gauges and good (NS $>$ $0.7, \mathrm{R}^{2}>0.75$, PBIAS $< \pm 10 \%$ ) for eight of them (Figure 9). Only PBIAS of Gauge 5 is unsatisfactory. The $\mathrm{R}^{2}$ and NS statistics range from 0.63 to 0.87 and 0.52 to 0.86 , respectively. The validation results confirm the efficiency of the model calibration, except of two linked Gauge 6 and Gauge 7. Further analysis showed that the unsatisfactory results derived from inadequate climate data representation. 
Table 5. List of SWAT's parameters that were fitted and their final calibrated values

\begin{tabular}{|c|c|c|c|c|}
\hline \multirow[t]{2}{*}{ Parameters } & \multirow[t]{2}{*}{ Definition } & \multirow{2}{*}{$\begin{array}{l}\text { Default } \\
\text { SWAT value }\end{array}$} & \multicolumn{2}{|c|}{ Final parameter value } \\
\hline & & & range & best $\operatorname{sim}$. \\
\hline r_CN2.mgt ${ }^{a}$ & Initial SCS runoff curve number for moisture condition II & $60-81$ & {$[-0.2,-0.3]$} & -0.234 \\
\hline v_ESCO.hru & Soil evaporation compensation factor & 1 & $0.4-0.6$ & 0.5445 \\
\hline v_SMFMX.bsn & Melt factor for snow on June $21, \mathrm{~mm} \mathrm{H}_{2} \mathrm{O} /{ }^{\circ} \mathrm{C}$-day & 4.5 & $0.5-1$ & 0.92 \\
\hline v_SMFMN.bsn & Melt factor for snow on December $21, \mathrm{~mm} \mathrm{H}_{2} \mathrm{O} /{ }^{\circ} \mathrm{C}$-day & 4.5 & $2-3.5$ & 3.21 \\
\hline v_SFTMP.bsn & Snowfall temperature, ${ }^{\circ} \mathrm{C}$ & 1 & $0-1$ & 0.06 \\
\hline v_SMTMP.bsn & Snow melt base temperature, ${ }^{\circ} \mathrm{C}$ & 0.5 & $-0.2-0.5$ & 0.16 \\
\hline a_SUB_TIMP.sno & \multirow[t]{7}{*}{ Snow pack temperature lag factor } & \multirow{7}{*}{1} & & \multirow{7}{*}{0.00975} \\
\hline - Forest $>50 \%$ & & & $0.1 \pm 0.05$ & \\
\hline - Forest $36-50 \%$ & & & $0.2 \pm 0.05$ & \\
\hline - Forest $26-35 \%$ & & & $0.3 \pm 0.05$ & \\
\hline - Forest $16-25 \%$ & & & $0.4 \pm 0.05$ & \\
\hline - Forest $11-15 \%$ & & & $0.5 \pm 0.05$ & \\
\hline - Forest $<11 \%$ & & & $0.6 \pm 0.05$ & \\
\hline a_SOL_AWC.sol & Available water capacity of the soil layer, $\mathrm{mm} \mathrm{H}_{2} \mathrm{O} / \mathrm{mm}$ soil & $0.12-0.2$ & \pm 0.02 & -0.019 \\
\hline r_SOL_K.sol & Saturated hydraulic conductivity, $\mathrm{mm} / \mathrm{hr}$ & $5.4-169$ & {$[-0.5,0.5]$} & 0.2125 \\
\hline v_DEP_IMP.hru & \multirow{3}{*}{$\begin{array}{l}\text { Depth to impervious layer for modeling perched water } \\
\text { tables, } \mathrm{mm}\end{array}$} & \multirow{3}{*}{6000} & & \\
\hline$-\operatorname{Sub}^{\mathrm{d}} 1,2$ & & & $2400-3600$ & 3388 \\
\hline - Sub 3 & & & $3400-4600$ & 4325 \\
\hline r_RCHRG_DP.gw & \multirow[t]{3}{*}{ Deep aquifer percolation fraction } & \multirow{3}{*}{0.05} & & \multirow{3}{*}[0.111]{} \\
\hline - Sub $1,4,5$ & & & $0.2 \cdot[-0.2,0.2]$ & \\
\hline - Sub 3, 6-12 & & & $0.5 \cdot[-0.2,0.2]$ & \\
\hline SURLAG.hru & \multirow[t]{6}{*}{ Surface runoff lag coefficient } & \multirow{6}{*}{4} & \multirow{2}{*}{\multicolumn{2}{|c|}{$1^{\mathrm{b}}$}} \\
\hline - Sub 1,2 & & & & \\
\hline - Sub 3, 4 & & & \multicolumn{2}{|l|}{0.3} \\
\hline - Sub 5 & & & \multicolumn{2}{|c|}{0.12} \\
\hline - Sub 6 & & & \multicolumn{2}{|c|}{0.8} \\
\hline - Sub 7-12 & & & \multicolumn{2}{|l|}{0.5} \\
\hline GWQMN.gw & \multirow{9}{*}{$\begin{array}{l}\text { Threshold depth of water in the shallow aquifer requied for } \\
\text { return flow to occur, } \mathrm{mm} \mathrm{H}_{2} \mathrm{O}\end{array}$} & \multirow[t]{9}{*}{1000} & \multirow{2}{*}{\multicolumn{2}{|c|}{3600}} \\
\hline - Sub 1 & & & & \\
\hline - Sub 2, 3 & & & \multicolumn{2}{|c|}{3000} \\
\hline - Sub 4 & & & \multicolumn{2}{|c|}{4200} \\
\hline - Sub 5 & & & \multicolumn{2}{|c|}{4800} \\
\hline - Sub 6,7 & & & \multicolumn{2}{|c|}{1000} \\
\hline - Sub $8,10,12$ & & & \multicolumn{2}{|c|}{2800} \\
\hline - Sub 9 & & & 2200 & \\
\hline - Sub 11 & & & 2000 & \\
\hline $\mathrm{v} \_\mathrm{CH} \_\mathrm{N} 2$. rte & Manning's " $n$ " value for the main channel & 0.014 & 0.15 & \\
\hline v_ALPHA_BF.gw & Baseflow alpha factor, $1 /$ days & 0.048 & 0.0044-0. & $256^{\mathrm{c}}$ \\
\hline
\end{tabular}

Note. $\quad{ }^{a}$ The qualifier $\left(\mathrm{v} \_\right.$) refers to the substitution of a parameter by a value from the given range, $\left(\mathrm{r} \_\right.$) refers to a relative change in the parameter were the current values is multiplied by 1 plus a factor in the given range, (a_) means a given value is added to the existing parameter value

${ }^{\mathrm{b}}$ The fixed values indicate that a parameter was fitted and then fixed

${ }^{c}$ Arnold's baseflow filter program values (https://swat.tamu.edu/software/baseflow-filter-program/)

${ }^{\mathrm{d}}$ Sub means subwatershed which fall into certain gauge catchment area 


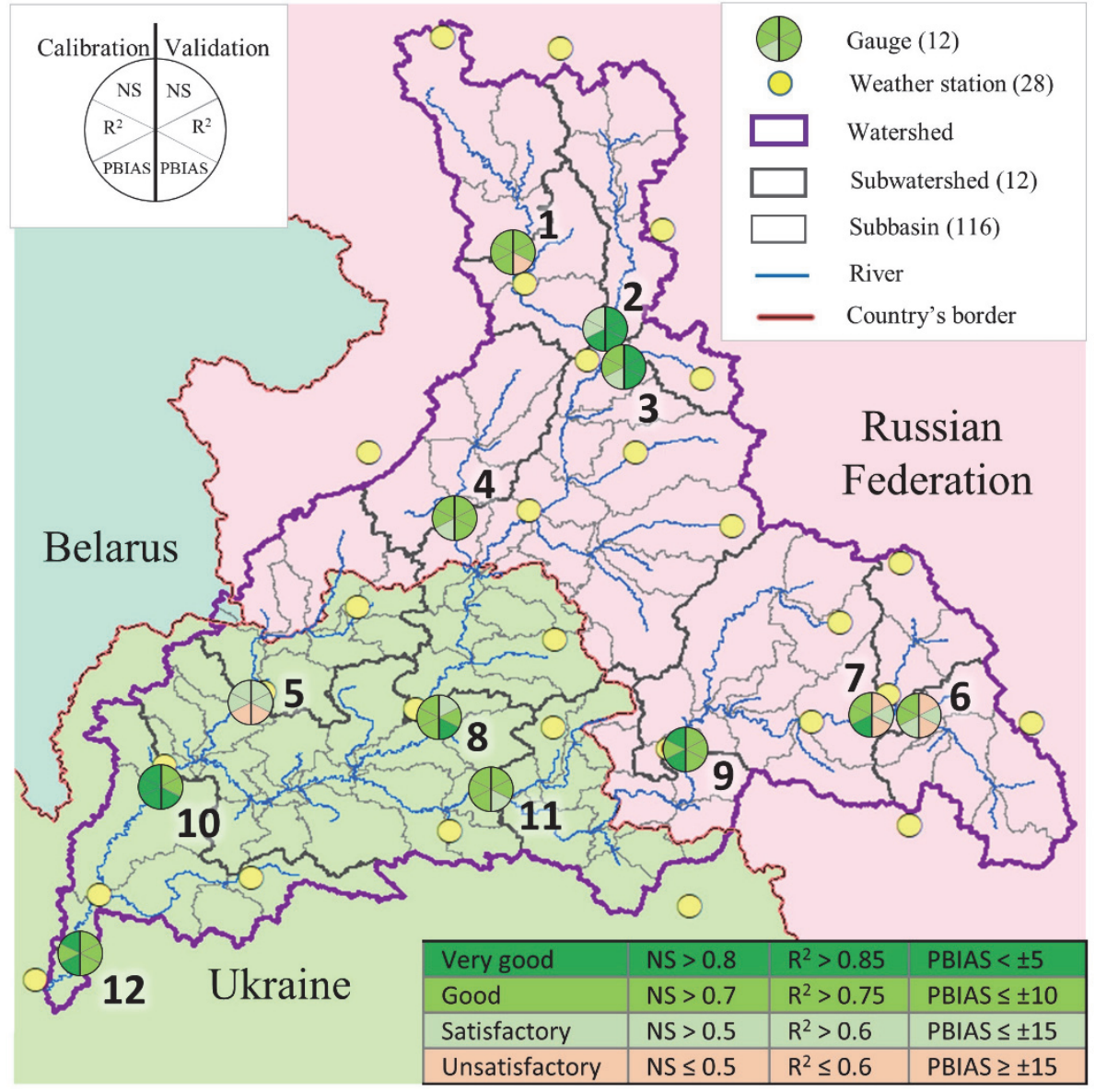

Figure 9. The calibration and validation results of streamflow at twelve gauges of the Desna basin. The performance evaluation criteria according to Moriasi et al., 2015.

Since 1989, the increase in the average annual temperature across the Desna catchment, especially the temperature of the winter-spring season (January-April), causes the reduction of annual runoff and maximum of spring flood flow, while the groundwater flow contribution increases, videlicet, from $45 \%$ to $55 \%$ in the last 20 years (Chornomoretz \& Grebin, 2010). The simulated period is a good example of such processes when the groundwater flow is the major part of the Desna river discharge (Table 6).

Table 6. Water balance components of the Desna watershed (2008 - 2014)

\begin{tabular}{|c|c|c|c|}
\hline Process & Output code & Average annual value & $\min -\max$. \\
\hline Precipitation, $\mathrm{mm}$ & PCP & 589 & $435-655$ \\
\hline Evapotranspiration, $\mathrm{mm}$ & ET & 411 & $386-430$ \\
\hline Percolation, mm & PERC & 137 & $66-202$ \\
\hline Water in shallow aquifer returning to root zone ${ }^{a}, \mathrm{~mm}$ & REVAP & 11 & 11 \\
\hline Water yield, $\mathrm{mm}$ & WYLD & $120.5(100 \%)$ & $98-175$ \\
\hline Surface runoff, $\mathrm{mm}$ & SURQ & $47(39 \%)$ & $13-89$ \\
\hline Lateral flow, mm & LATQ & $5.5(4.6 \%)$ & $3.1-6.8$ \\
\hline Groundwater flow, mm & GWQ & $68(56.4 \%)$ & $48-82$ \\
\hline
\end{tabular}

Note. ${ }^{a}$ this value is conditional because it is not sensitive parameter in the calibration process

\section{Discussion}

When modeling small subbasins, the 95PPU captures less observations (lower p-factor), which is explained by the low special coverage of precipitation inputs. Accordingly, some of the precipitation is missed, and the part, on the contrary, "superfluous" (Figure 10). Probably, inadequate precipitation inputs are the reason of underestimation of 
the Gauge 1 hydrograph peaks because the magnitude matching is good for the downstream Gauge 3 (Figure 11).

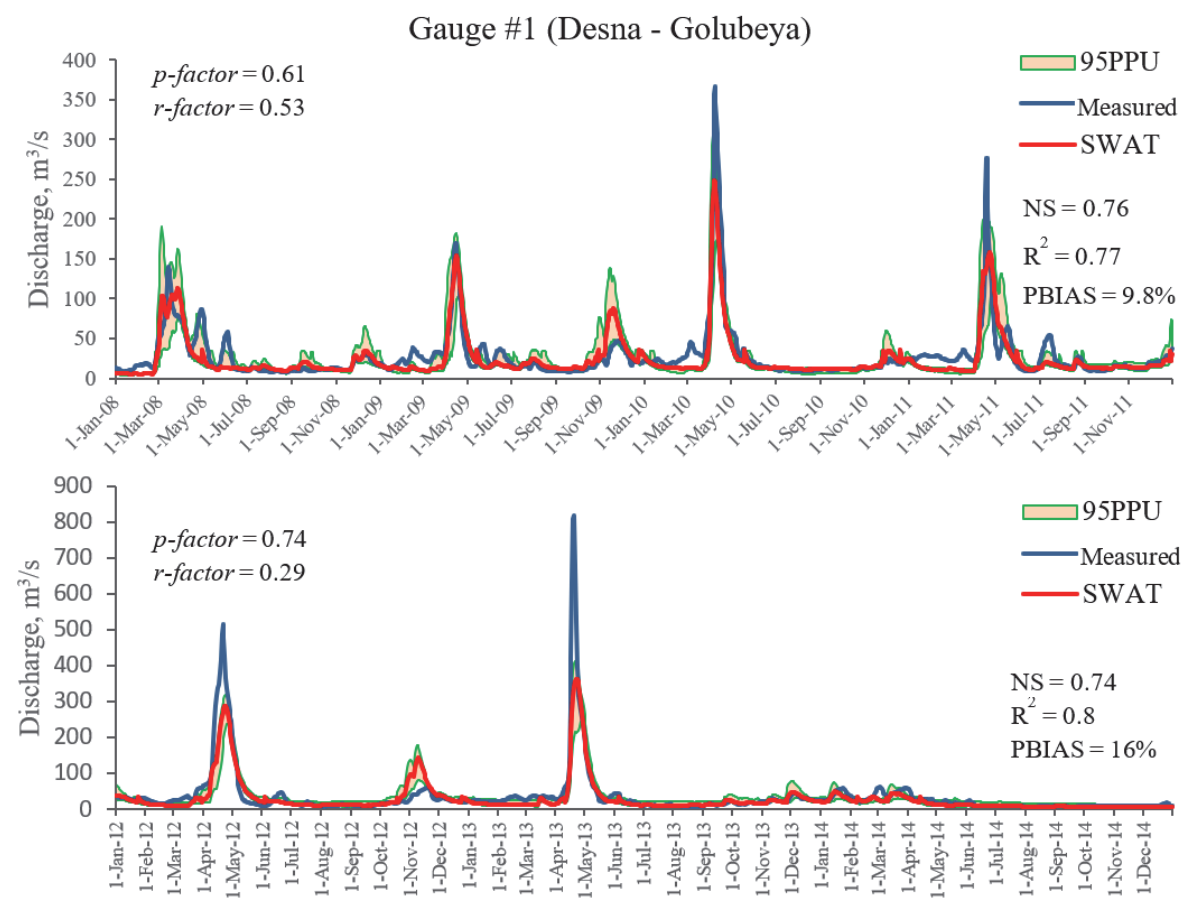

Figure 10. Measured flow, 95\% model uncertainty, and best simulation at Gauge 1 after calibration (2008-2011) and validation (2012-2014).
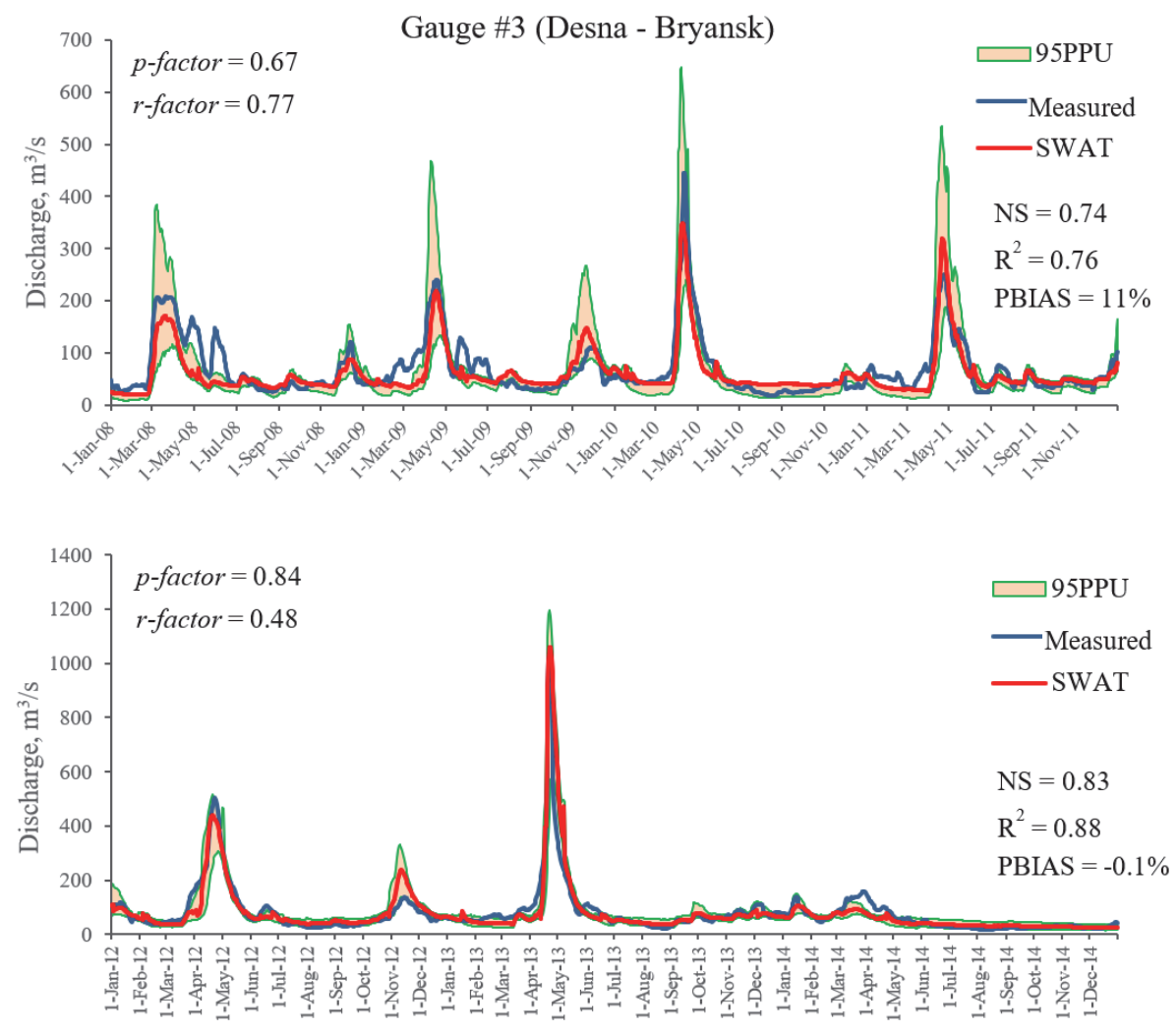

Figure 11. Measured flow, 95\% model uncertainty, and best simulation at Gauge 3 after calibration (2008-2011) and validation (2012-2014).

With the increase in the number of weather stations, the likelihood of overestimating or underestimating of 
precipitations is minimized, since one station compensates the other. Therefore, the $p$-factor and the evaluation criteria are higher for the downstream gauges (Figure 12).
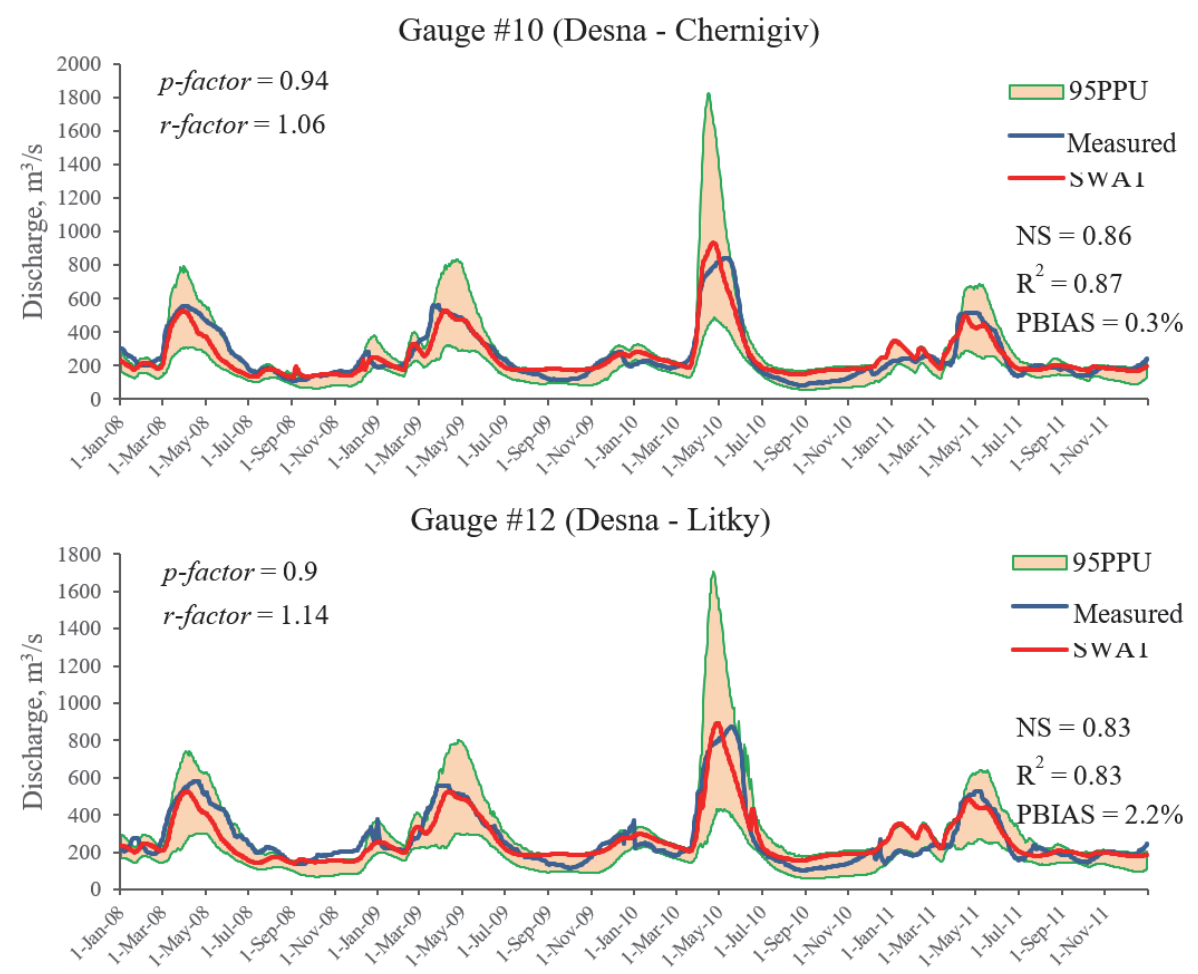

Figure 12. Measured flow, 95\% model uncertainty, and best simulation at Gauge 10 and Gauge 12 after calibration (2008-2011) and validation (2012-2014).

Figure 13A and Figure 13B show that in 2013, the main part of the snow is concentrated in the northern, central, and eastern parts of the basin, and in 2010 - in the central and western parts. The simulated distribution of the snow layer depends on the location of the weather stations and coincides for the subbasins, which are influenced by one station, except those that are significantly different in the forest cover area. The surface runoff ratio during spring flood correlates with weather station cover as well; and it, often strongly contrasts between neighboring subbasins. Hence, it can be concluded that climate data (precipitation, temperature) is the key factor that determines the shape of the hydrograph; otherwise, a correlation would be observed with the spatial variability of soils or land cover.

Table 7. Comparison of Subbasins 22 and 27 characteristics and spring flood water balance components simulated by SWAT in 2010 (20.03 - 4.04) and $2013(31.03-19.04)$

\begin{tabular}{|c|c|c|c|c|c|c|c|c|c|c|c|}
\hline \multirow[t]{2}{*}{ Sub } & \multirow[t]{2}{*}{$\begin{array}{l}\text { Weather } \\
\text { station }\end{array}$} & \multirow[t]{2}{*}{ Forest, $\%$} & \multirow[t]{2}{*}{$\begin{array}{l}\text { Crop } \\
\text { lands, \% }\end{array}$} & \multirow[t]{2}{*}{$\begin{array}{l}\text { Soil hydrological } \\
\text { group }\end{array}$} & \multirow[t]{2}{*}{ SURLAG } & \multicolumn{2}{|c|}{$\begin{array}{l}\text { Snowmelt, } \\
\mathrm{mm}\end{array}$} & \multirow{2}{*}{$\begin{array}{l}\text { Surface } \\
\mathrm{mm} \\
2010\end{array}$} & runoff, & \multicolumn{2}{|c|}{$\begin{array}{l}\text { Surface runoff/ } \\
\text { Snowmelt }\end{array}$} \\
\hline & & & & & & 2010 & 2013 & & 2013 & 2010 & 2013 \\
\hline 22 & Navlya & 41 & 48 & $\mathrm{C}$ & 0.5 & 128 & 183 & 37 & 18 & 0.29 & 0.1 \\
\hline 27 & Dmitrovsk & 35 & 57 & $\mathrm{C}$ & 0.5 & 141 & 163 & 26 & 56 & 0.19 & 0.34 \\
\hline 87 & Tim & 9 & 78 & $\mathrm{C}$ & 0.8 & 115 & 142 & 7 & 14 & 0.06 & 0.1 \\
\hline 104 & Oboyan & 11 & 77 & $\mathrm{C}$ & 0.8 & 120 & 173 & 58 & 80 & 0.49 & 0.46 \\
\hline
\end{tabular}



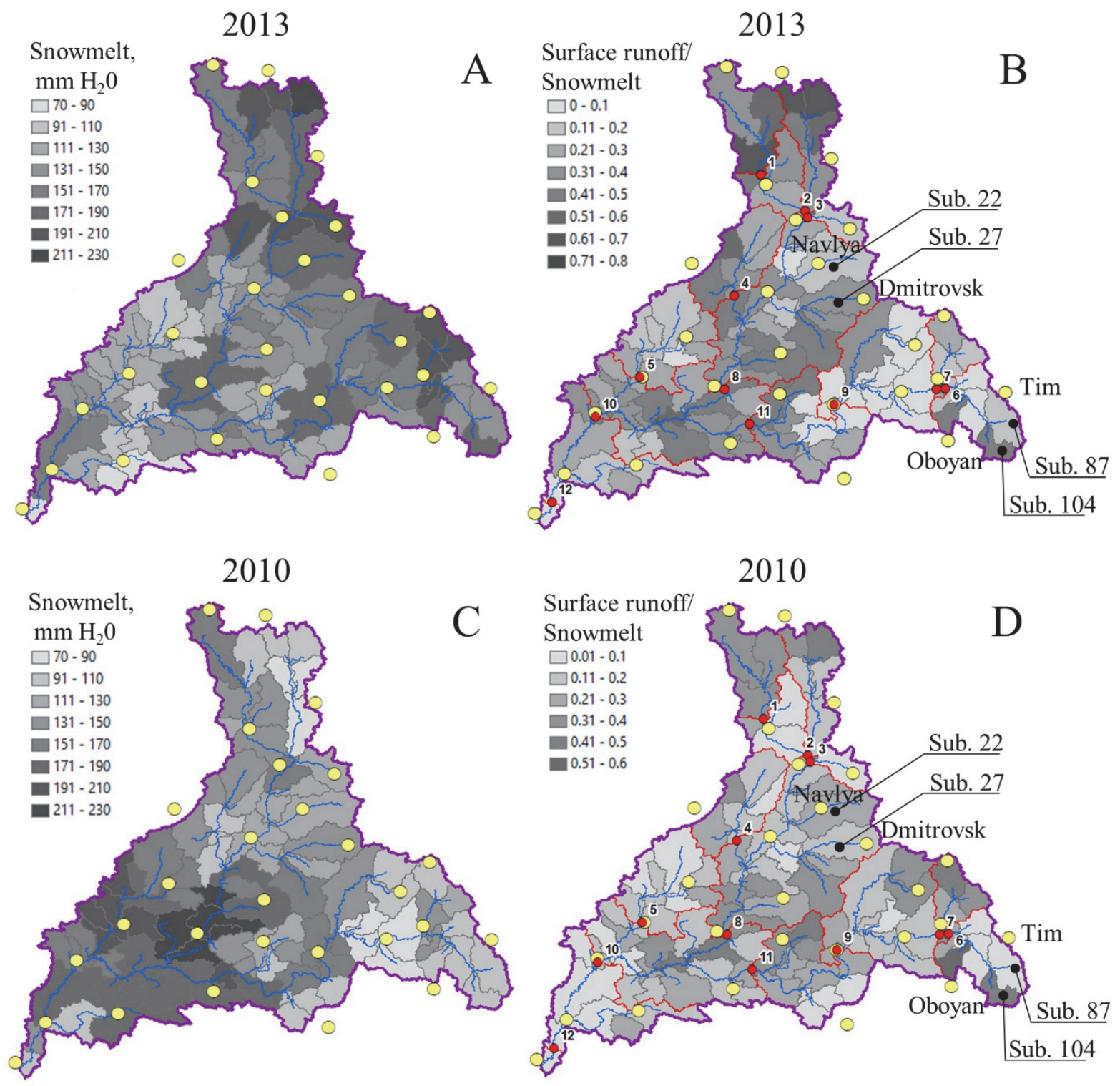

Figure 13. Comparison of snowmelt $\left(\mathrm{H}_{2} \mathrm{O}\right)$ and surface runoff/snowmelt ratio during spring flood in 2013 (A, B) and in $2010(\mathrm{C}, \mathrm{D})$.

Considering more in-depth analysis of Subbasins 22 and 27, 87 and 104, which refer to Gauge 8 and Gauge 6, respectively (Table 7). Subbasins 22 and 27 are very similar in characteristics of land cover, soils and have the same time of surface runoff concentration (SURLAG) but are influenced by the different weather stations - Navlya and Dmitrovsk, respectively. In 2010 for Subbasin 22, the snowmelt depth was $128 \mathrm{~mm} \mathrm{H}_{2} \mathrm{O}$ during spring flood (20.03 - 4.04), which formed $37 \mathrm{~mm}$ of surface runoff, the runoff ratio was 0.29. For Subbasin 27, the snow cover was $141 \mathrm{~mm}$ but surface runoff was lower $-26 \mathrm{~mm}$, the ratio was 1.5 times smaller than for Subbasin 22 . Interestingly, the situation was opposite in 2013 - with comparable values of snow cover, the runoff ratio was 3 times higher for Subbasin 27. For Subbasins 87 and 104, the difference was more contrast regardless almost identical characteristics. This example shows that a climate data can cause significant runoff difference during snowmelt period and unsatisfactory calibration results.

The difference in the amount of surface runoff was due to the difference of $\mathrm{CN}$ values which was formed in the autumn due to the distinction in rainfall and kept during the whole winter when the soil was frozen (Figure 14). 

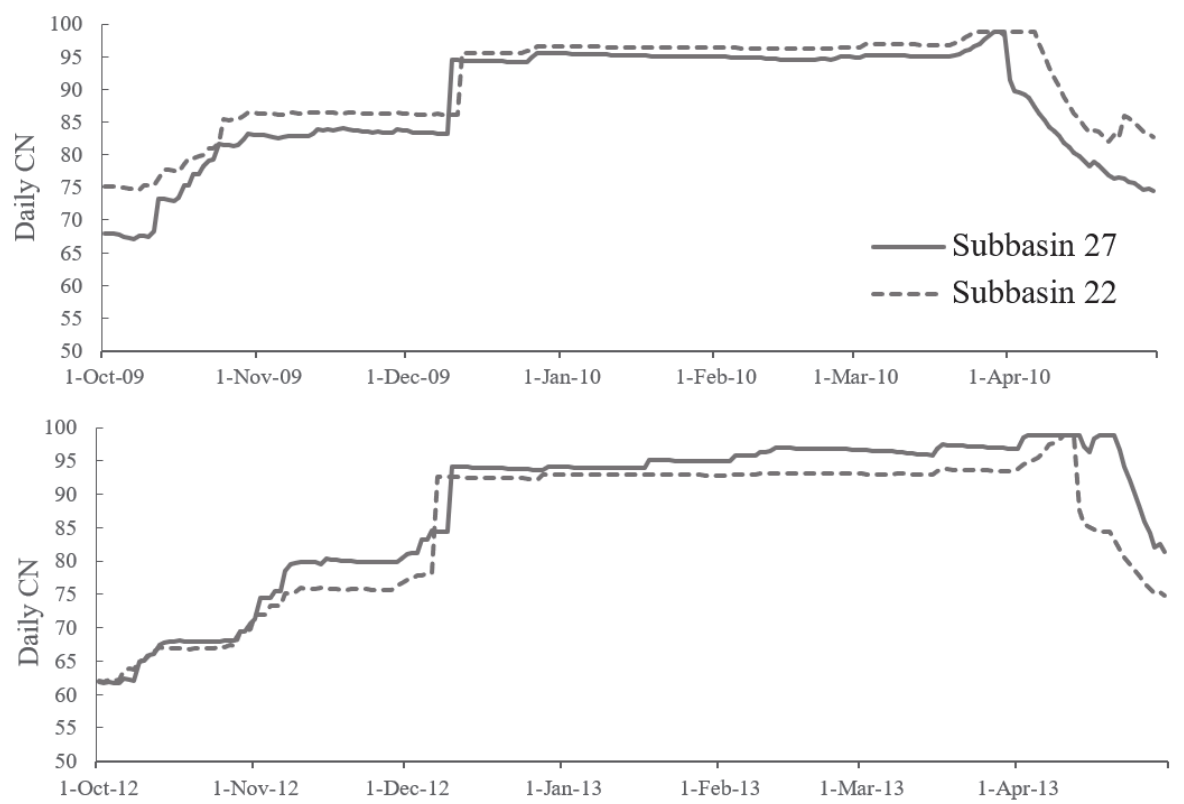

Figure 14. Daily CN comparison of the similar hydrological response units (HRUs) of Subbasins 22 and 27 (landuse: Agricultural land close-grown, soil: Grey forest, slope: 0-3\%). In 2010, the daily CN is greater for the HRU of Subbasin 22; in 2013, for the HRU in Subbasin 27

\section{Conclusions}

The approach proposed in this study using SWAT model provides significant insight into calibration process of a plain snowmelt-driven watershed with a daily time step. The calibration was based on snow cover depth (13 stations), river discharge (12 stations), along with soft data constraints on surface flow and evapotranspiration. The date of snow cover loss was identified as a key factor of successful calibration because of its linkage with the peak discharge timing of spring flood hydrograph. This date may not be captured by regression-based calibration approach, therefore, the manual visual inspection of snow cover time-series plots is more reliable. Furthermore, the forest snow cover dynamics differs from uncovered lands which has been reflected in the subbasin-scale snow pack temperature lag factor (TIMP) optimization during calibration.

The calibration and validation results were good for eight out of twelve outlets and satisfactory for all of them, except of validation of two upstream linked gauges. The program SUFI-2 in SWAT-CUP package was used to quantify the $95 \%$ prediction uncertainty of the outputs. Overall, the agreement is higher for the downstream outlets due to more adequate spatial coverage of precipitation inputs for the whole watershed versus one site.

The SWAT model for the Desna watershed could be used to calculate cross-boundary water transfers, perform flood risk assessment, and conduct climate change studies. The article provides a detail source data information that will facilitate data collection and data assembling for the transboundary Ukrainian-Russian watershed-scale models.

\section{Acknowlegments}

The work was carried out with funding the Volkswagen Foundation of the project "Management of Transboundary Rivers between Ukraine, Russia and the EU - Identification of Science-Based Goals and Fostering Trilateral Dialogue and Cooperation (ManTra-Rivers)" (Az.: 90 426). The authors are grateful to Serhii Filipchuk for text editing.

\section{References}

Abbaspour, K. C. (2015). SWAT-CUP - A User Manual. EAWAG. Retrieved from http://swat.tamu.edu/software/swat-cup/

Abbaspour, K. C., Rouholahnejad, E., Vaghefi, S., Srinivasan, R., Yang, H., \& Kløve, B. (2015). A continentalscale hydrology and water quality model for Europe: Calibration and uncertainty of a high-resolution largescale SWAT model. J. Hydrol., 524, 733-752. https://doi.org/10.1016/j.jhydrol.2015.03.027

Arnold, J. G., Moriasi D. N., Gassman P. W., Abbaspour K. C., White M. J., Srinivasan, R., Santhi, C., Harmel, R. 
D., van Griensven, A., Van Liew, M. W., Kannan N., ... Jha M. K. (2012). SWAT: Model use, calibration, and validation. Trans. ASABE, 55(4), 1491-1508. https://doi.org/10.13031/2013.42256

Chornomoretz, Y., \& Grebin, V. (2010). Elements of water river balance annual distribution of Desna Basin and their annual fluctuations. Hydrology, hydrochemistry, hydroecology, 1(18), 98-106.

Douglas-Mankin, K. R., Srinivasan, R., \& Arnold, J. G. (2010). Soil and Water Assessment Tool (SWAT) model: Current development and applications. Trans. ASABE, 53(5), 1423-1431. https://doi.org/10.13031/2013.34915

EAWAG. (2009). SWAT-CUP. Dübendorf, Switzerland: Swiss Federal Institute of Aquatic Science and Technology. Retrieved from http://www.eawag.ch/organisation/abteilungen/siam/software/swat/index_EN

Esri Mapping Center, University of Montana. World Evapotranspiration Web Viewer. Retrieved from http://www.arcgis.com/apps/OnePane/main/index.html?appid=b1a0c03f04994a36b93271b0c39e6c0f

European Atomic Energy Community, European Union, The Member States, \& Ukraine. (2014). Association Agreement between the European Union and its Member States, of the one part, and Ukraine, of the other part. Official Journal of the European Union. Retrieved November 10, 2017, from http://eurlex.europa.eu/legal-content/EN/ALL/?uri=CELEX:22014A0529(01).

Gassman, P. W., Reyes, M. R., Green, C. H., \& Arnold, J. G. (2007). The Soil and Water Assessment Tool: Historical development, applications, and future research directions. ASABE, 50(4), 1211-1250. https://doi.org/10.13031/2013.23637

Gassman, P. W., Sadeghi, A. M., \& Srinivasan, R. (2014) Applications of the SWAT Model Special Section: Overview and Insights. Journal of Environmental Quality, 43(1), 1-8. https://doi.org/10.2134/jeq2013.11.0466

Grebin V. V., Vasylenko E. V. (2010). Methodological underground constituent in the nourishment of the rivers. Hydrology, hydrochemistry, hydroecology, 4(21), 8-15.

Hlotka, D. (2017). GlobeLand30 LULC and Global Forest Change geodata merging for environmental modelling. Geographical Journal, 69(1), 61-73.

Hrebin, V. V. (2010) Current water regime of the Ukraine rivers: Landscape-hydrological analysis. Kyiv: NicaCenter.

ICPDR - International Commission for the Protection of the Danube River. (2015). The Danube River Basin District Management Plan. Retrieved from http://www.icpdr.org/main/activities-projects/river-basinmanagement-plan-update-2015.

Koshkina, O. V. (2017). Factors, parameters and current tendencies of the maximum runoff of spring flood in the Desna river basin. - The qualification scientific work as a manuscript (Doctoral dissertation). UHMI, Kyiv, Ukraine.

Kyivvodokanal. Retrieved July 27, 2018, from https://vodokanal.kiev.ua/upravl\%D1\%96nnyaekspluatacz\%D1\%96\%D1\%97-desnyansko\%D1\%97-vodoprov\%D1\%96dno\%D1\%97stancz $\% \mathrm{D} 1 \% 96 \% \mathrm{D} 1 \% 97-($ ue-dvs).

Loboda, N. S. (2011). The influence of climatic changes on Ukrainian water resources: Modeling and prediction. Kyiv, Nica-Center.

Malone, R. W., Yagow, G., Baffaut, C., Gitau, M. W., Qi, Z., Amatya, D. M., Parajuli, P. B., Bonta, J. V., ... Green, T. R. (2015). Parameterization guidelines and considerations for hydrologic models. Trans. ASABE, 58(6), 1681-1703. https://doi.org/10.13031/trans.58.10709

Maps of Ukraine. Retrieved from http://geomap.land.kiev.ua/soil-6.html

Marynich, A. M., \& Shishchenk P. G. (2005). Physical-geography of Ukraine. Kiev: Znannya.

Matveev, L. T. (1984). General meteorology course: Physics of the atmosphere. Leningrad: Gidrometeoizdat.

Medvedev, V. V., \& Laktionova, T. N. (2011). Texture of Ukrainian Soils: Genetic, environmental and agronomical aspects. Kharkiv: Apostrof.

Medvedev, V. V., Laktionov, T. M., \& Gayvoronsky, I. V. (2006). Atlas of soil properties maps of Ukraine (electronic version). Kharkiv.

Ministry of Ecology and Natural Resources of Ukraine. (2015). The National Report on the State of Environment. 
Retrieved from https://menr.gov.ua/news/31768.html.

Moriasi, D. N., Gitau, M. W., Pai, N., \& Daggupati, P. (2015). Hydrologic and Water Quality Models: Performance Measures and Evaluation Criteria. ASABE, 58(6), 1763-1785. https://doi.org/10.13031/trans.58.10715

Moriasi, D.N., Zeckoski, R. W., Arnold, J. G., Baffaut, C. B., Malone, R. W., Daggupati, P., Guzman, J. A., Saraswat, D., Yuan, Y., Wilson, B. W., Shirmohammadi, A., ... Douglas-Mankin, K. R. (2016). Hydrologic and water quality models: key calibration and validation topics. Trans. ASABE, 58(6), 1609-1618.

NLCD - National Land Cover Database. Retrieved from https://www.mrlc.gov/nlcd92_leg.php.

Osadchy, V., Nabyvanets, B., Linnik, P., Osadcha, N., \& Nabyvanets, J. (2016). Processes Determining Surface Water Chemistry. Springer. https://doi.org/10.1007/978-3-319-42159-9

Osadchy, V., Osadcha, N., \& Nabyvanets, Ju. (2003). Chemical composition and water quality of surface waters in Ukraine. Proceedings of Second International Conference on the Impact of Environmental factors on Health "Environmental Health Risk II" (pp. 15-24). Catania, Italy. Southampton, Boston: WIT Press. https://doi.org/10.2495/EHR030021

Palamarchuk, M.M., \& Zakorchevna N.B. (2006). Water fund of Ukraine. Kyiv: Nica-Center.

Photovoltaic Geographical Information System - Interactive Maps. Retrieved January 10, 2018, from http://re.jrc.ec.europa.eu/pvgis/apps4/pvest.php.

Qiaozhen, M., Maosheng, Z., \& Steven, W. R. (2013). Algorithm Theoretical Basis Document: MODIS Global Terrestrial Evapotranspiration (ET) Product (NASA MOD16A2/A3). Collection 5. NASA Headquarters.

Sokolovsky, D. L. (1968). River flow: the basis of the theory and methodology of calculations. L.: Gidrometeoizdat.

Tuppad, P., Douglas-Mankin, K. R., Lee, T., Srinivasan, R., \& Arnold, J. G. (2011). Soil and Water Assessment Tool (SWAT) hydrologic/water quality model: Extended capability and wider adoption. Trans. ASABE, 54(5), 1677-1684. https://doi.org/10.13031/2013.39856

USRSRR - Unified State Register of soil resources in Russia. Retrieved from http://atlas.mcx.ru/materials/egrpr/content/data.html.

Wellen, C., Kamran-Disfani, A.-R., \& Arhonditsis, G. B. (2015) Evaluation of the Current State of Distributed Watershed Nutrient Water Quality Modeling. Environ. Sci. Technol, 49, 3278-3290. https://doi.org/10.1021/es5049557

Yatsik, A. V. (2004). Vodogospodarska ekologiya: Water management ecology. Kyiv: Geneza.

\section{Copyrights}

Copyright for this article is retained by the author(s), with first publication rights granted to the journal.

This is an open-access article distributed under the terms and conditions of the Creative Commons Attribution license (http://creativecommons.org/licenses/by/4.0/). 